\title{
The Readability of Reading Texts in English Textbook Used by Senior High School Students in West Sumatera
}

\author{
Miftaahurrahmi, Fitrawati, and HErmawati Syarif \\ English Department, FBS, Universitas Negeri Padang \\ West Sumatera, Indonesia \\ amiftaahurrahmi2503@gmail.com
}

\begin{abstract}
Readability is one of the criteria to choose reading texts for students. Brown (2012) says that readability is a concept that describes the degree to which a text is easy or difficult to read. Also, Arias (2007) mentions that the material selected needs to be suitable for the students' level. This research was conducted to know the readability of reading texts in English textbook used by senior high school students in West Sumatera. Due to the fact that this textbook (Look Ahead: An English Course for senior high school students year XII Published by Erlangga Publisher) is still used at most of senior high schools in West Sumatera, it is needed to investigate the readability of the reading texts provided in this textbook. The research was done descriptively by using Reading Ease Formula by Flesch. The result of this research revealed that the reading texts in this textbooks do not fulfill the readability criteria. From 10 samples of reading texts, only 1 text is suitable for senior high school students year XII.
\end{abstract}

Keywords: reading text, readability, readability formula

\section{INTRODUCTION}

Everybody who learns a language needs to master reading skill beside three other skills: listening, speaking, and writing. In English language learning activity, reading skill is important to measure whether the students could understand English written forms well. The other fact that shows how important the reading skill is that information or texts are provided in written forms compared to the spoken ones. If the students have poor reading skill, they would not understand the text even they get the information. Moreover, reading is the interaction between the reader and the writer. The reader needs to catch what the writer is trying to encode to get the correct information. Furthermore, in high school, for example, reading is the core because through reading the students can find new things to improve their pronunciation, translation ability, and other skills. Thus, those are the reasons why reading skill is important so that English teachers who teach reading should pay serious attention to this.

One important thing to be considered in reading activity is the text. To improve students' reading comprehension, teachers need to prepare the appropriate reading texts for the students. If the text is too difficult, the students will be stressed. In contrast, if it is too easy, they will not get an accurate count of their ability. Because of the reason, the teacher must look for the suitable reading text for the students.

There is no doubt that the suitable reading texts should meet the criteria of good written text. There are some experts that come with the ideas about the criteria. There are three things to be considered while choosing reading texts for students: First, suitability of content, the students should find the texts absorbing, attractive, challenging, and apposite for their goals. Second, exploitability, the texts should assist the attainment of certain language and content goals, which is exploitable for instructional tasks and techniques, and allied with other skills. Last, readability, a text with lexical and structural difficulty will challenge students without overwhelming them [1].

In addition, four factors that the teacher should pay attention in choosing the text, such as: students level, the text selected needs to be suitable for the students level; students' interest, the text should be based on the students' interest; students' needs, considering the students' need in the text selection; and students' background knowledge, the text should be easy to recognize [2]. She also added some important aspects related to the text which are relevance, relevant for the students' life; content, the content must be interesting, and authenticity, the texts must be authentic.

In accordance with the theories above, those experts states one similar point to judge the reading texts. It is the readability of the texts. Readability is the match between readers and the text. Readability suggests that content is clear, well expressed, and suited to the readers. It is to judge the conditions within the reader and within the text, which will create a successful connection [3]. Readability is one of the criteria to choose reading texts for students, and the material selected needs to be suitable for the students' level, so that the definition of readability brought by Richardson is match well to the theory of criteria of a good written text. To conclude, readability relates to the level of the texts whether it is easy to read and understand also suitable for the students level $[1,2$, $3]$.

To meet this criterion, there have been many English textbooks that provide reading texts published. One of them is "Look Ahead: An English Course" Textbook for Senior High School Students Year XII written by Sudarwati and Eudia 
Grace which published by Erlangga Publisher. Based on the preliminary research, even though there are many English textbooks published, most of Senior High School English teachers in West Sumatera tend to use this textbook. It is supported by the research done by Yulizar [4].

"Look Ahead: An English Course" Textbook for Senior High School Students Year XII was published in 2006 which is suitable for School Based Curriculum (KTSP). Even though in 2013 there is new curriculum released which is called 2013 Curriculum, not all school in West Sumatera apply this curriculum. Most of them still use KTSP. Based on the latest data from Indonesian Educational Department on 2016, from 213 senior high schools in West Sumatera, only 47 schools apply the 2013 Curriculum. It means that 166 others still use $K T S P$. From this data, it can be seen that more senior high schools use KTSP than the 2013 Curriculum. The reason is that the government still advance the 2013 Curriculum both the teaching practice and material. Actually, there is no much difference between KTSP and the 2013 Curriculum. It is only the teaching practice like assessment, the teaching material is still the same. Thus, "Look Ahead: An English Course" Textbook for Senior High School Students Year XII which is suited for KTSP is still use by most of senior high school in West Sumatera until now.

On account of this phenomenon, the researcher thinks that it is important to evaluate the readability of texts in this textbook; how the level of difficulty of the texts is and how suitable the texts are for the students level. "Look Ahead: An English Course" Textbook for Senior High School Students Year XII published by Erlangga Publisher is chosen as the research subject because it is the highest level textbook for high school which provides high level texts that the students must comprehend. Another reason to choose this textbook is because it is suggested to use it in teaching and learning activity by the educational department.

\section{FLESCH READING EASE FORMULA}

In case, the most common and the most publicized readability formula was credited to Rudolf Flesch (1948). The popularity of this formula made Flesch a leading authority on readability. Flesch Reading Ease Formula rates texts on a 100point scale; the higher the score, the easier it is to understand the document. Most standard passages have approximately a readability score of 60 to 70 [5].

The Flesch Reading Ease Formula is multiplying the average number of syllables per word in the text by 84.6 , then subtracts the result from 206.835. From this result, the equation subtracts 1.015 times the average number of words per sentence [6]. The actual reading ease index is:

\section{$\mathrm{RE}=206.835$ - $(\mathbf{1 . 0 1 5} \times \mathrm{ASL}) \boldsymbol{-}(\mathbf{8 4 . 6} \times \mathrm{ASW})$}

Where: RE stands for Reading Ease, ASL is Average Sentence Length (the number of words divided by the number of sentences), and ASW is Average Number of Syllables per Word (the number of syllables divided by the number of words).

Flesch sets directions to use the formula by giving series of steps:

1) Count the words
Count each word in the up to 100. After the $100^{\text {th }}$ word, put a mark. If there are numbers, symbols, contractions, hyphenated words, abbreviations, figures, and their combination that are surrounded by one space, count them as one word. For instance, count the following as a single word; 2016, \$ 25.3, CO, doesn't, top-down.

2) Count the sentences within the 100 words

Count a sentence of full units of speech marked by a period, colon, semicolon, dash, question mark, or exclamation point as one sentence. Sometimes a 100word mark falls in the middle of a sentence. If the 100word mark falls after more than half of words in that sentence, count it as one sentence; otherwise disregarded.

3) Count the number of syllables

Count the syllables as they are pronounced, for example: marked has one syllable, ancient consists of two, people has three, celebrating consists of four syllables. If a word has two accepted pronunciations, use the one with fewer syllables. To illustrate, the word beloved has two kinds of pronunciation (bilavd and bilavId), choose the fewer one. Count the number of syllables in symbols and figures according to the way they are normally pronounced, two syllables for $\$$ (dollar), three for EFL (e-ef-el), and four for 1960 (nineteen sixty).

4) Find the readability score

Find the average number of score and word length of the text in the readability table. The instruction of readability score shows on the reading ease score.

The Flesch Reading Ease Formula is a number from 0 to 100 , with a higher score indicating easier reading. If we were to draw a conclusion from the formula, then the bets text should contain shorter sentences and words. The score between 60 and 70 is largely considered acceptable, it has standard as the description of style and the estimated reading grade is eighth to ninth grade. If we find a result of readability with other score, we can compare it with the other criteria in the table. The following table is the readability score index by Flesch, which is helpful to assess the ease of readability in a reading text: 


\begin{tabular}{|c|c|c|c|c|}
\hline $\begin{array}{c}\text { Description of } \\
\text { Style }\end{array}$ & $\begin{array}{c}\text { Average } \\
\text { Sentences } \\
\text { Length in } \\
\text { Words }\end{array}$ & $\begin{array}{c}\text { Average } \\
\text { No. of Syll. } \\
\text { Per 100 } \\
\text { Words }\end{array}$ & $\begin{array}{c}\text { Reading } \\
\text { Ease } \\
\text { Score }\end{array}$ & $\begin{array}{c}\text { Estimated } \\
\text { Reading } \\
\text { Grade }\end{array}$ \\
\hline Very Easy & 8 or less & 123 or less & $90-100$ & Fifth Grade \\
\hline Easy & 11 & 131 & $80-90$ & Sixth Grade \\
\hline Fairly Easy & 14 & 139 & $70-80$ & Seventh Grade \\
\hline Standard & 17 & 147 & $60-70$ & $\begin{array}{c}\text { Eighth to Ninth } \\
\text { Grade }\end{array}$ \\
\hline Fairly Difficult & 21 & 155 & $50-60$ & $\begin{array}{c}\text { Tenth to Twelfth } \\
\text { Grade }\end{array}$ \\
\hline Difficult & 25 & 167 & $30-50$ & $\begin{array}{c}\text { Thirteenth to } \\
\text { Sixteenth Grade } \\
\text { (College) }\end{array}$ \\
\hline Very Difficult & 29 or more & 192 or more & $0-30$ & $\begin{array}{c}\text { College } \\
\text { Graduated }\end{array}$ \\
\hline
\end{tabular}

The question is, is this formula valid to use for EFL? Unfortunately, the formula's validity for EFL/ESL use has gone largely untested. Two studies have now addressed this issue, with divergent results. Brown said that the classic formulas were not very accurate predictor for EFL difficulty then he made his own readability formula, while Greenfield found that these formulas predicted for EFL about as well as they did for native English readers [7, 8]. On the other hand, Brown's formula proves more accurate with the other study's passages than with his own, agreeing with observed EFL difficulty and predictions by classic formulas. This supports the finding that the classic formulas are valid for EFL use. Based on this evidence, the researcher chooses to use the classic formula, here the Flesch Reading Ease Formula.

\section{METHOD}

This research described the readability level of texts. Relating to this, the researcher used descriptive method in describing the readability level of the texts. The descriptive research shows the way things are; what really occurs in the field [9]. This research includes all practice and instruments involve in gathering and compiling the data to make judgments about things to be analyzed [10]. By using this type of research, the researcher analyzed the reading texts provided in "Look Ahead: An English Course" Textbook for Senior High School Students Year XII published by Erlangga Publisher. This research described the readability of those reading texts.

The subject of this research was English textbook entitled "Look Ahead: An English Course" Textbook for Senior High School Students Year XII published by Erlangga Publisher. As mentioned above, many Senior High School English teachers in West Sumatera use this English textbook [4] and the readability of reading texts has not been analyzed yet.

Moreover, the researcher focused on the reading skill that is broadened to five units in this English book (Sudarwati, 2007). The reading texts from the first until the fifth unit are: Unit 1 is Telling Stories (Halloween, p.20, and The History of Jack and the Beanstalk, p.32); Unit 2 is Finding Out Why It Happens (Sound Recordings and Reproduction, p.69, and Tsunami p, 73); Unit 3 is Pros and Cons (The Advantages and the Disadvantages of Nuclear Energy, p. 102, and Cloning of Animal: Allowed or Not Allowed?, p.117); Unit 4 is Tell Me the Story (The Wrestling Match, p.139, and Ockok the Owl and Wak the Hawk, p. 147); Unit 5 is Thinking Critically (The Jungle Book 2, p. 171, and Spiderman 2 - the Review, p. 185). Furthermore, the instrument used is an analysis format, which adapts the Flesch Reading Ease Score Index.

\section{FINDING AND DISCUSSION}

To find the reading ease of the texts, the researcher used Flesch Reading Ease Formula. In using this formula, the researcher counted the words, sentences, syllables of the texts, so that the score gotten could be used in the formula. The very first step was counting the words up to 100 words and put a mark on it. After the $100^{\text {th }}$ word, put a mark. If there are numbers, symbols, contractions, hyphenated words, abbreviations, figures, and their combination that are surrounded by one space, counted them as one word Then, the researcher counted how many sentences within the 100 words text long. The next step was counting the syllables.

After the scores of this counting process were gotten, the next step was measuring the readability of each text based on the Flesch Reading Ease Formula. The formula is: RE = 206.835 - (1.015 x ASL) - (84,6 x ASW) Where: RE stands for Reading Ease, ASL is Average Sentence Length (the number of words divided by the number of sentences), and ASW is Average Number of Syllables per Word (the number of syllables divided by the number of words); Afterthat, the researcher put the result in the analysis format The results of this counting process is presented in the analysis format below: 


\begin{tabular}{|c|c|c|c|c|c|c|}
\hline No & Text & $\begin{array}{l}\text { Average Sentences } \\
\text { Length in Words }\end{array}$ & $\begin{array}{c}\text { Average } \\
\text { No. of Syll. Per } 100 \\
\text { Words } \\
\end{array}$ & $\begin{array}{c}\text { Reading } \\
\text { Ease } \\
\text { Score } \\
\end{array}$ & $\begin{array}{l}\text { Description } \\
\text { of Style }\end{array}$ & $\begin{array}{c}\text { Estimated } \\
\text { Reading } \\
\text { Grade } \\
\end{array}$ \\
\hline 1 & Text 1 & 25 & 160 & 46.1 & Difficult & $\begin{array}{l}13^{\text {th }} \text { Grade } \\
\text { (College) }\end{array}$ \\
\hline 2 & Text 2 & 16.7 & 127 & 82.5 & Easy & $6^{\text {th }}$ Grade \\
\hline 3 & Text 3 & 16.7 & 169 & 46.9 & Difficult & $\begin{array}{l}13^{\text {th }} \text { Grade } \\
\text { (College) }\end{array}$ \\
\hline 4 & Text 4 & 20 & 161 & 50.3 & $\begin{array}{l}\text { Fairly } \\
\text { Difficult }\end{array}$ & $12^{\text {th }}$ Grade \\
\hline 5 & Text 5 & 16.7 & 176 & 41.0 & Difficult & $\begin{array}{l}15^{\text {th }} \text { Grade } \\
\text { (College) }\end{array}$ \\
\hline 6 & Text 6 & 14.3 & 153 & 62.9 & Standard & $9^{\text {th }}$ Grade \\
\hline 7 & Text 7 & 11.1 & 140 & 77.1 & Fairly Easy & $7^{\text {th }}$ Grade \\
\hline 8 & Text 8 & 10 & 121 & 94.3 & Very Easy & $5^{\text {th }}$ Grade \\
\hline 9 & Text 9 & 50 & 147 & 31.7 & Difficult & $\begin{array}{l}16^{\text {th }} \text { Grade } \\
\text { (College) }\end{array}$ \\
\hline 10 & Text 10 & 14.3 & 143 & 71.4 & Fairly Easy & $7^{\text {th }}$ Grade \\
\hline \multicolumn{2}{|c|}{ Average } & 19.5 & 150 & 60.4 & $\begin{array}{c}\text { Fairly } \\
\text { Difficult }\end{array}$ & $\begin{array}{c}10^{\text {th }}-12^{\text {th }} \\
\text { Grade }\end{array}$ \\
\hline
\end{tabular}

Unfortunately, based on the readability analysis of the reading texts which follows the Flesch Reading Ease Formula, the researcher found an unsatisfying result. In accordance with Flesch Reading Ease Formula, the text that is suitable for the $12^{\text {th }}$ grade of senior high school students should be in fairly difficult level with the range of Reading Ease Score arround 50 to 60 . However, the data on analysis format shows that from the analysis of 10 reading texts, only one text that is suitable for the $12^{\text {th }}$ grade of senior high school students. The text is Text 4 entitled Tsunami that has the reading ease score 50.3 .

If it is seen in the level of difficulty, the findings showed that there are variation of style. There result showed that there is one very easy text that is Text 8 entitled Ockok the Owl and Wak the Hawk. Besides, there is also an easy texts that is Text 2 entitled The History of Jack and the Beanstalk. Also, there are two fairly easy texts, which are Text 7 entitled The Wrestling Match and Text 10 entitled Spiderman 2-the Review.

In addition, there is also one standard text that is Text 6 entitled Cloning of Animals: Allowed or Not Allowed. Moreover, there is one fairly difficult text that is Text 4 entitled Tsunami. Furthermore, there are four difficult texts, which are Text 1 entitled Halloween, Text 3 entitled Sound Recordings and Reproduction, Text 5 entitled The Advantages and Disadvantages of Nuclear Energy, and Text 9 entitled The Jungle Book 2.

Even though the average result showed that the reading texts in "Look Ahead: An English Course" Textbook for Senior High School Students Year XII published by Erlangga Publisher is fairly difficult, it is important to notice that there is only one text that is in this level. According to Flesch Reading Ease Score Index, the text that is suitable for $12^{\text {th }}$ grade students should be in fairly difficult level. It means that the texts, which are in very easy, easy, fairly easy, standard, and difficult level should be deleted or revised to become fairly difficult.

Besides, if it is seen in the suitability of the texts for the students level, the findings showed that the texts are suitable for several grades of students. Two texts are suitable for elementary school students grade $5^{\text {th }}$ and $6^{\text {th }}$. The texts are Text 8 entitled Ockok the Owl and Wak the Hawk and Text 2 entitled The History of Jack and the Beanstalk.Also, there are three texts are suitable for junior high school students. Text 7 entitled The Wrestling Match and Text 10 entitled Spiderman 2-the Review are suitable for the $7^{\text {th }}$ graders while Text 6 entitled Cloning of Animals: Allowed or Not Allowed is suitable for the $9^{\text {th }}$ graders.

Moreover, there is only one text that is suitable for the $12^{\text {th }}$ grade of senior high school students, which is Text 4 entitled Tsunami while the rest is suitable for college students. Text 1 entitled Halloween and Text 3 entitled Sound Recordings and Reproduction are suitable for $13^{\text {th }}$ graders (first semester of college students. Further, Text 5 entitled The Advantages and Disadvantages of Nuclear Energy is suitable for $15^{\text {th }}$ graders (third semester of college students) while Text 9 entitled The Jungle Book 2 is suitable for $16^{\text {th }}$ graders (fourth semester of college students).

Even though the average result showed that the reading texts in "Look Ahead: An English Course" Textbook for Senior High School Students Year XII published by Erlangga Publisher is suitable for $12^{\text {th }}$ graders, it must be noticed that there is only one text that is in this level. Because the text book analyzed is for senior high school students year XII, the result above presented that 9 texts are not suitable for this level. Thus, the texts which are suitable for elementary school, junior high school, and college students must be revised to be in senior high school students year XII level. 
At a glance, the percentage of appropriate texts in the findings of the current research indicates that the readability of the texts used by the writers seemed to be ignored. It could be caused by the lack of understanding toward the concept of readability. Readability means that the good written text is a text with lexical and structural difficulty will challenge students without overwhelming them [1]. Also, readability means that the texts should cogitate the reading ease so that the reader is able to comprehend the explanation of the text. Regarding the findings of the current research, it can be assumed that the writers only took or adopt the texts by skipping readability analysis because of the lack of understanding toward this concept [11]. Thus, the texts which are not suitable for the students current grade, which means that the texts that is not in fairly difficult level and appropriate for grade XII students should be revised [12]. ।

\section{CONCLUSION AND RECOMMENDATION}

Based on the findings of this research, it can be concluded that the analysis of the readability of texts provided in "Look Ahead: An English Course" Textbook for Senior High School Students Year XII published by Erlangga Publisher is needed in order to know how is the level of difficulty by the students and how suitable the texts are for the students level. According to Flesch Reading Ease Formula, the readability results showed that the the level of difficulty of the texts in "Look Ahead: An English Course" Textbook for Senior High School Students Year XII published by Erlangga Publisher are not in the level that they shoul be and not suitable for the senior high school students year XII. From the 10 texts being analyzed, only one text that is suitable for the senior high school students year XII. It means that this textbook cannot longer be used in teaching and learning activity for the senior high school students year XII .

After doing this research, the researcher will give suggestions related to this study. First, for the textbook and test developer, it is suggested to consider the readability of the texts whether it is in exact level of difficulty and suitable for the students level so that the students can read the texts that are easier to understand and more interesting because the texts are on their grade. So, for the writers of Look Ahead: An English Course Textbook, before taking or adapting texts to be put in students textbook, it is a must to consider the criteria of reading text for the students in a certain grade, in this case considering the readability of the text.

\section{References}

[1]Nuttal.1996. The use of authentic materials in the teaching of reading. https://scholar.google.co.id/scholar?q=Nuttall,+1996+on + Readability\&hl=id\&as_sdt=0\&as_vis $=1 \&$ oi $=$ scholart \& $\underline{\mathrm{sa}=X \& v e=0 \text { ahUKEwiwgqmNnaHOAhUBMo8KHQHh }}$ B8oQgQMIIDAA (downloaded on April 2016)
[2]Arias, Ivannia Jimenez. 2007. Selecting Reading Material Wisely. Costa Rica: Univercidad Nacional. www.revistas.una.ac.cr/index.php/ . (downloaded on January, 2016)

[3]Richardson, Judy S. 2012. Reading to learn in the Content Areas. USA: Wadswort.

Standar Isi SMA 2006. BNSP

Sudarwati, Th.M., Eudia Grace. 2007. Look Ahead: An English Course for Senior High School Students Year XII. Jakarta: Penerbit Erlangga.

[4]Yulizar. 2012. A Textbook Analysis of "Look Ahead and English Course for Senior High School Students Year $X$." Unpublished Thesis. Padang: UNP.

[5]Zamanian. 2012. Readability of Texts: Staye of the Art. Finland: Academy Publisher. http://search.proquest.com/openview/66fd6dfe36e2bc18 bc5fdbd659180e34/1?pq-origsite $=$ gscholar $($ downloaded on March 2016)

[6]Renkema. 2004. Introduction to Discourse Studies.Amsterdam/Philadelphia: John Benjamin Publishing Company.

[7]Brown, J.D. 2012. A Preliminary Study of Cloze Procedure as A Tool for Estimating English Readability for russian Students. Manoa: University of Hawai'i. http www.hawaii.edu/sls/wp-content/uploads/.../Brown-etal.pdf (downloaded on March 2016)

[8]Greenfield, G. (1999). Classic readability formulas in EFL context: Are they valid for Japanese speakers? Temple University: University Microfilm.

[9]Gay. 2000. Multicultural teacher education for the 21st century.

http://www.tandfonline.com/doi/abs/10.1080/088787300 09555246 (downloaded on March 2016)

[10]Brown. 2002. Do Cloze Test Work or it Just an Illusion : Second Language Studies. http://www.academia.edu/3745465/Brown_J. D. 2002 .Do_cloze tests_work_Or_is_it_just_an_illusion_Seco nd Language Studies 21 1 1 79-125 (downloaded on March 2016)

[11]Waller, Rob. 2011. What makes a good document? The criteria we use. www.simpli!cationcentre.org.uk. University of Reading. (downloaded on January, 2016)

[12]Bailin, Alan, Ann Grafstein. 2016. Readability: Text and Context. New York: Palgrave Macmillan. 